\title{
Water-Soluble Distyrylbenzene Fluorophore and Fluorescence Behavior in a Polymeric Vesicle
}

\author{
Rati Ranjan Nayak - 우한영* \\ 부산대학교 나노정보.소재공학과(BK21) \\ (2007.11. 16 접수)
}

\section{Water-Soluble Distyrylbenzene Fluorophore and Fluorescence Behavior in a Polymeric Vesicle}

\author{
Rati Ranjan Nayak and Han Young Woo* \\ Department of Nanomateriats Engineering (BK2l), Pusan Nationol Liniversith, Minang 627-706, Korea \\ (Received November 16, 2007)
}

\begin{abstract}
요 약. 수용액에서 vesicle을 형성하는 고분자, poly(sodium acrylamidoundecanoate)(PSAU)와 수용성 형광다이, TPADSB-C를 합섬하고 흡수 및 형광 분광기를 이용하여 광학적 특섬을 연구하였다. N-phenyl naphthylamine을 형광 probe로 사용하여 PSAU의 농도가 $0.01 \mathrm{~g} / \mathrm{L}$ 이상에서 고분자들의 응집에 의해 vesicle을 형섬함을 확인하였다. 수용성 형광다이의 형광 특성을 vesicle의 존재유무에 따라 조사핱으로써 형광다이 주위의 미세환경의 변화에 따른 광학적 특성 의 변화를 측정하였다. 형광다이를 고분자 vesicle안에 침투시킬 경우 형광체 주변의 미세 환경(극성 등)의 변화에 따라 수용액 대비 발광 파장은 blue-shift하였고 형광 효율도 $90 \%$ 로 증가하였다. 본 연구는 형광다이를 함유하고 있는 고분 자 vesicle이 바이오이메징 응용에 있어 효과적이고 안정적이면서 biocompatible한 레이볼용 테그로 사용될 수 있음을 보여준다.
\end{abstract}

주제어: Vesicle, Fluorescence, Water-soluble Chromophore, Distyrylbenzene, Microenviromment

ABSTRACT. A vesicle forming polymer, poly(sodium acrylamidoundecanoate) (PSAU) and a water-soluble distyylbenzene-based fluorophore, TPADSB-C were synthesized and characterized by using UV-vis and photoluminescence (PL) spectroscopy. An inter-chain vesicle fomation of PSAU was observed at $-0.01 \mathrm{~g} / \mathrm{L}$ from $\mathrm{N}$-phenyl naphthylamine fluorescence measurement with changing PSAU concentration in water. Above critical aggregation concentration of PSAU, optical properties of TPADSB-C were investigated to study the microenvironment modulation through dye incorporation in the polyneric vesicle. The emission of TPADSB-C in the presence of PSAU vesicles was blue-slifted and the PL quantum efficiency was increased to $90 \%$ due to the microenviromment (e.g. polarity) change in aqueous solution. This study shows that the polymeric vesicle containing molecular florophores has a great potential as an efficient, stable and biocompatible labeling tag in biological cell imaging.

Keywords: Vesicle. Fluorescence, Water-soluble Chromophore, Distyrylbenzene. Microenvironment

\section{INTRODLCTION}

Among the various microstructures formed by the anphiphilic molecules, a vesicle is an especially interesting structure as it has two distinct domains, the lipophilic menibrane and the interior aqueous cavity. It can entrap large quantities of chenicals (or molecules) either in the lipophilic menibrane or in the aqueous cavity. Therefore, vesicles fomed by synthetic surfactants have attracted 
tremendous attention because of their potential uses as agents for encapsulation and eventual release of drugs, flavors, and fragrances, and also as nicroreactors for the synthesis of monodispersed nanosized scmiconductor particles. ${ }^{1-6}$ The microstructures formed by the amphiphiles are in dynanic equilibrium with the surfactant monomers in solution. One way to obtain structural stabilization of the molecular self-assemblies is chemically tethering the surfactant monomers through polymerization. Polymerication prevents the surlactant reorganization necessary for the lormation of reversed micelles and flip-flop. The vesicles formed by polysoaps are reported to be more stable and less pemeable than respective monomeric ones.? Therefore, polymerized vesicles are expected to act as an exeellent micro-container for chemicals such as cosmetic substances and pharmaceutical drugs. The polymerized vesicles are well known structures as a bionimetic system which is capable of carrying out celllike functions. ${ }^{8}$

In this contribution, we report the synthesis and optical characterizations of a vesicle-forming amphiphilic polymer, poly(sodium acrylanidoundecanoate) (PSAU) and a water-soluble distyrylbenzene-based lluorophore, TPADSB-C (Fig. 1). Inter-chain vesicle formation of PSAU, the chromophore inclusion in the vesicle and its optical properties with/without the vesieles were studied by using UV-vis and photoluminescence (PL) spectroscopy. The mieroenvironment modulation around the fluorophores using the vesicles is discussed in terms of utilizing then as optical tags in biological cell inaging.

\section{EXPERIMENTAL}

All chemicals except acryloyl chloride (TCI) were purchased from Aldrich Chemical Co. and used without further purification. All solvents used were of reagent-grade and whenever necessary purified, dried, and distilled before use. 'H NMR spectra were recorded on a JEOL (JNM-AL300) FT NMR system. UV-visible spectra were measured with a Jasco (model V-630) spectrophotometer. The steady-state fluorescence spectra were measured on a Jasco FP-6500 specirolluorometer. $\Lambda$ salurated solution of the probe, N-phenyl naphthylamine (NPN) was prepared by adding an excess compound to deionized water wilh slirring at $40^{\circ} \mathrm{C}$ for $24 \mathrm{~h}$. After equilibration at room temperature, the remaining undissolved molecules were removed by filtration through Millipore syringe filter $(0.22 \mathrm{~mm})$. A polymer stock solution $(2 \mathrm{~g} / \mathrm{L})$ was prepared in the above probe solution. Appropriate volume of the saturated probe solution was used to make various dilutions of the polymer stock solution. All fluorescence spectra were measured at equilibration (after 24 hrs) after sample preparation.

Synthesis of PSAU. PSAU was obtained by free radical polymerization of sodium acrylamidoundecanoatc ( $\mathrm{SAU}$ ) in water using $\mathrm{K}_{2} \mathrm{~S}_{2} \mathrm{O}_{8}$ as a radical initiator at $60^{\circ} \mathrm{C}$ under a $\mathrm{N}_{2}$ atmosphere according to the procedures reported elsewhere." The polymer solution was dialyzed for $72 \mathrm{~h}$ using $12 \mathrm{kDa}$ molecular weight cut off dialysis bag against alkaline water $(\mathrm{pH}-10)$ and lyophilized to get dry PSAU. 'H-NMR

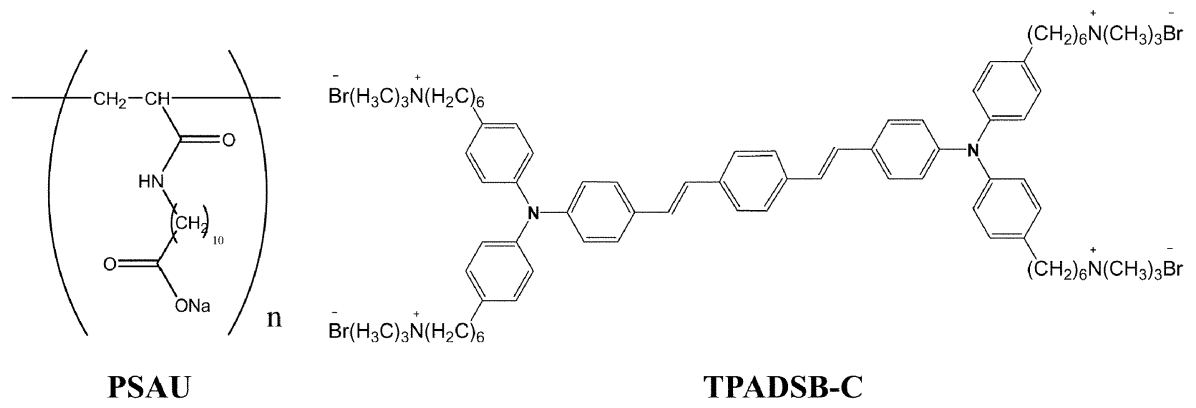

Fig. I. Chemical structures of PSAU and TPADSB-C. 
for SAL $\left(300 \mathrm{MHz}, \mathrm{CDCl}_{3}\right): \delta 6.29(\mathrm{~d}, 1 \mathrm{H}), 6.06$ (dd, 1H), 5.59 (d, 1H), 3.27 (qt, 2H), 2.3 (t, 2H), 1.5 (br, 4H), 1.21 (br, 12H). The polymerization was confirmed by the disappearance of the vinyl proton peaks at $\delta=5 \sim 7 \mathrm{ppm}$ in the ${ }^{\mathrm{l}} \mathrm{H}$ NMR spectrum of PSAU in $\mathrm{D}_{2} \mathrm{O}$.

N,N-Bis[4'-(6"-bromohexyl)phenyl]-4-aminobenzaldehyde (1). A $100 \mathrm{~mL}$ round-botton flask containing $30 \mathrm{~mL}$ of dry DMF was cooled down to $0^{\circ} \mathrm{C}$. Phosphorous oxybromide $(1.2 \mathrm{~g}, 4.2 \mathrm{mmol})$ was added maintaining the temperature below $5^{\circ} \mathrm{C}$. The reaction mixture was stirted for $30 \mathrm{~min}$. A white solid was observed to be precipitated. $\mathrm{Bis}[4-$ (6'-bromohexyl)phenyl]phenylamine ( $0.8 \mathrm{~g}, 1.4 \mathrm{mmol}$ ) in $10 \mathrm{~mL}$ of dry DMF was added to the above solution and the temperature was slowly increased to $90^{\circ} \mathrm{C}$. After the solution was heated ovemight, it was cooled down to room temperature and poured into cold water. The $\mathrm{pH}$ of the solution was adjusted to around 7 with aqueous $\mathrm{NaOH}$ solution. The product was extracted with dichloromethane, dried over magnesium sulfate, and purified by silica gel colunn chromatography (ethyl acetate/hexane $(v / v)=1 /$ 10). The product yield was $0.67 \mathrm{~g}(80 \%)$. ${ }^{1} \mathrm{H}-\mathrm{NMR}$ (300 MHz, CDCl $\left.)_{3}\right): 9.79(\mathrm{~s}, 1 \mathrm{H},-\mathrm{CHO}), 7.66$ (d, $2 \mathrm{H}, \mathrm{J}=8.8 \mathrm{~Hz}), 7.15(\mathrm{~d}, 4 \mathrm{H}, \mathrm{J}=8.4 \mathrm{~Hz}), 7.09(\mathrm{~d}$, $4 \mathrm{H}, \mathrm{J}=8.4 \mathrm{~Hz}), 6.96(\mathrm{~d}, 2 \mathrm{H}, \mathrm{J}=8.8 \mathrm{~Hz}), 3.42(\mathrm{t}$, $\left.4 \mathrm{H},-\mathrm{CH}_{2} \mathrm{Br}, \mathrm{J}=6.8 \mathrm{~Hz}\right), 2.6 \mathrm{l}(\mathrm{t}, 4 \mathrm{H}, \mathrm{ArCH}-, \mathrm{J}=$ $7.8 \mathrm{~Hz}), 1.88(\mathrm{~m}, 4 \mathrm{H}), \mathrm{l} .66(\mathrm{~m}, 4 \mathrm{H}), 1.50(\mathrm{~m}, 4 \mathrm{H})$, $1.40(\mathrm{~m}, 4 \mathrm{H}) .{ }^{13} \mathrm{C}-\mathrm{NMR}\left(100 \mathrm{MHz}, \mathrm{CDCl}_{3}\right): \delta 190.6$, $153.8,143.8,139.9,131.5,129.8,128.6,126.6$, $118.5,35.5,34.2,32.9,31.4,28.6,28.2$. HRMS (EI): $\mathrm{m} / \mathrm{z}=597.1268\left(\mathrm{M}^{+}\right), \Delta=4.3 \mathrm{ppm}$.

1,4-Bis [N,N-bis(4"-(6"'-bromohexyl)phenyl)-4'aminostyryl]benzene (TPADSB-N). A $50 \mathrm{~mL}$ twonecked flask charged with 1,4-bis(diethylphosphonatemethyl)benzene $(0.14 \mathrm{~g}, 0.37 \mathrm{mmol})$ and $2.2 \mathrm{eq}$. of aldehyde $1(0.5 \mathrm{~g}, 0.83 \mathrm{mmol})$ in $20 \mathrm{~mL}$ of dry THF was cooled down to $0^{\circ} \mathrm{C}$ with an ice bath. To the above solution, $0.83 \mathrm{~mL}(2.2 \mathrm{eq})$ of potassium tert-butoxide (in THF, $1 \mathrm{M}$ ) was added dropwise at $0^{\circ} \mathrm{C}$. The reaction mixture was stirted for 6 hrs at $0^{\circ} \mathrm{C}$ and then quenched with water. The solvent was renoved under reduced pressure and the resulting mixture was diluted with dichloromethane, washed with water and brine, and dried over magnesiun sulfate. The crude compound was purified by silica gel column chromatography (dichloromethane/hexane $=1 / 5)$. The product yield was $0.38 \mathrm{~g}(80 \%)$. 'H-NMR (300 MHz, CDCl$)$ ): ठ $7.47(\mathrm{~s}, 4 \mathrm{H}), 7.38(\mathrm{~d}, 4 \mathrm{H}, \mathrm{J}=8.8 \mathrm{~Hz}), 7.09 \sim$ $7.01(\mathrm{~m}, 22 \mathrm{H}), 6.98(\mathrm{~d}, 2 \mathrm{H}, \mathrm{J}=16 \mathrm{~Hz}), 3.43(\mathrm{t}$, $\left.8 \mathrm{H},-\mathrm{CH} \mathrm{H}_{-} \mathrm{Br}, \mathrm{J}=6.8 \mathrm{~Hz}\right), 2.59\left(\mathrm{t}, 8 \mathrm{H}, \mathrm{ArCH}_{2}-\mathrm{J}\right.$ $=7.6 \mathrm{~Hz}), 1.89(\mathrm{~m}, 8 \mathrm{H}), 1.65(\mathrm{~m}, 8 \mathrm{H}), 1.50(\mathrm{~m}$, $8 \mathrm{H}), 1.40(\mathrm{~m}, 8 \mathrm{H}) .{ }^{13} \mathrm{C}-\mathrm{NMR}(100 \mathrm{MHz}$, $\left.\mathrm{CDCl}_{3}\right): \delta 147.9,145.5,137.6,136.9,131.0$, $129.4,128.1,127.4,126.8,126.4,124.8,122.8$, $35.5,34,3,33.0,31.5,28.7,28.3 . \mathrm{MS}$ (FAB): m/ $\mathrm{z}=1264\left(\mathrm{M}^{+}\right)$.

1, 4-Bis [N,N-bis(4"-(6""-(N,N,N-trimethylammonium)hexyl)phenyl)-4'-aminostyryl]benzene tetrabromide (TPADSB-C). To a solution of TPADSB$\mathbf{N}(0.15 \mathrm{~g}, 0.12 \mathrm{mmol})$ in THF $(20 \mathrm{~mL})$, was added an excess of condensed trimethylanine $(2 \mathrm{~mL})$ using a dry ice/acetone filled gas condenser at $-78^{\circ} \mathrm{C}$. The reaction mixture was allowed to warn to room temperature slowly and stirred for $12 \mathrm{hrs}$. A small amount of water was added to the above solution to dissolve the precipitated conpounds and the reaction solution was cooled down to $-78^{\circ} \mathrm{C}$ with a dry ice/ acetone bath. An excess of condensed trimethylamine $(2 \mathrm{nIL})$ was added again and the resulting solution was allowed to reach room tenperature and stirred for additional 12 lirs. After the reaction was completed, the remaining trimethylamine and solvent were removed under reduced pressure. A crude product was dissolved in a minimun anount of hot methanol and precipitated into diethyl ether several tines. The yield was $0.15 \mathrm{~g}(85 \%)$. ${ }^{\mathrm{H}} \mathrm{H}-\mathrm{NMR}$ (300 MHz, DMSO): $\delta 7.55(\mathrm{~s}, 4 \mathrm{H}), 7.48(\mathrm{~d}, 4 \mathrm{H}, \mathrm{J}=$ $8.8 \mathrm{~Hz}), 7.20(\mathrm{~d}, 2 \mathrm{H}, \mathrm{J}=16.4 \mathrm{~Hz}), 7.15(\mathrm{~d}, 8 \mathrm{H}, \mathrm{J}=8.4$ $\mathrm{Hz}), 7.08(\mathrm{~d}, 2 \mathrm{H}, \mathrm{J}=\mathrm{l} 6.4 \mathrm{~Hz}), 6.96(\mathrm{~d}, 8 \mathrm{H}, \mathrm{J}=8.4 \mathrm{~Hz})$, $6.88(\mathrm{~d}, 4 \mathrm{H}, \mathrm{J}=8.8 \mathrm{~Hz}), 3.28(\mathrm{n}, 8 \mathrm{H}), 3.05(\mathrm{~s}, 36 \mathrm{H})$, $2.55(\mathrm{t}, 8 \mathrm{H}, \mathrm{ArCH}-, \mathrm{J}=7.6 \mathrm{~Hz}), \mathrm{l} .68(\mathrm{~m}, 8 \mathrm{H}), \mathrm{l} .60$ $(\mathrm{n}, 8 \mathrm{H}), 1.36(\mathrm{~m}, 16 \mathrm{H})$. MS (ESI): $\mathrm{m} / \mathrm{z}=671(\mathrm{M}-2 \mathrm{Br})^{2+}$, $421(\mathrm{M}-3 \mathrm{Br})^{3-}, 296(\mathrm{M}-4 \mathrm{Br})^{4+}$. 


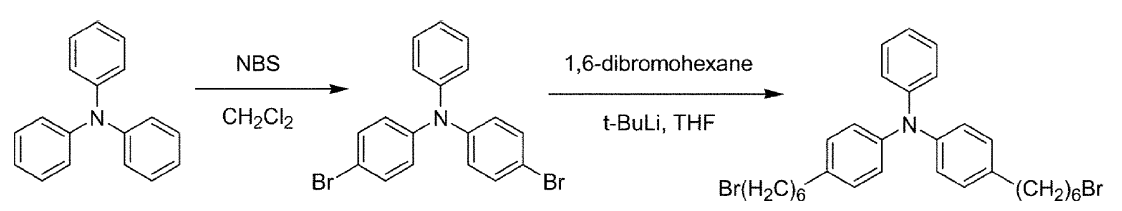

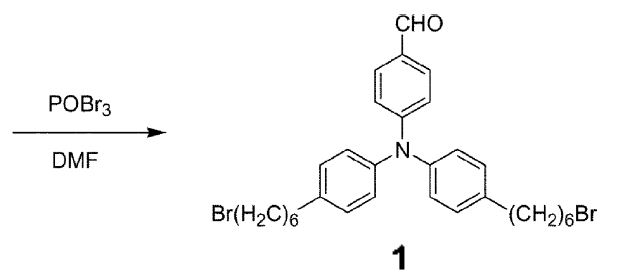

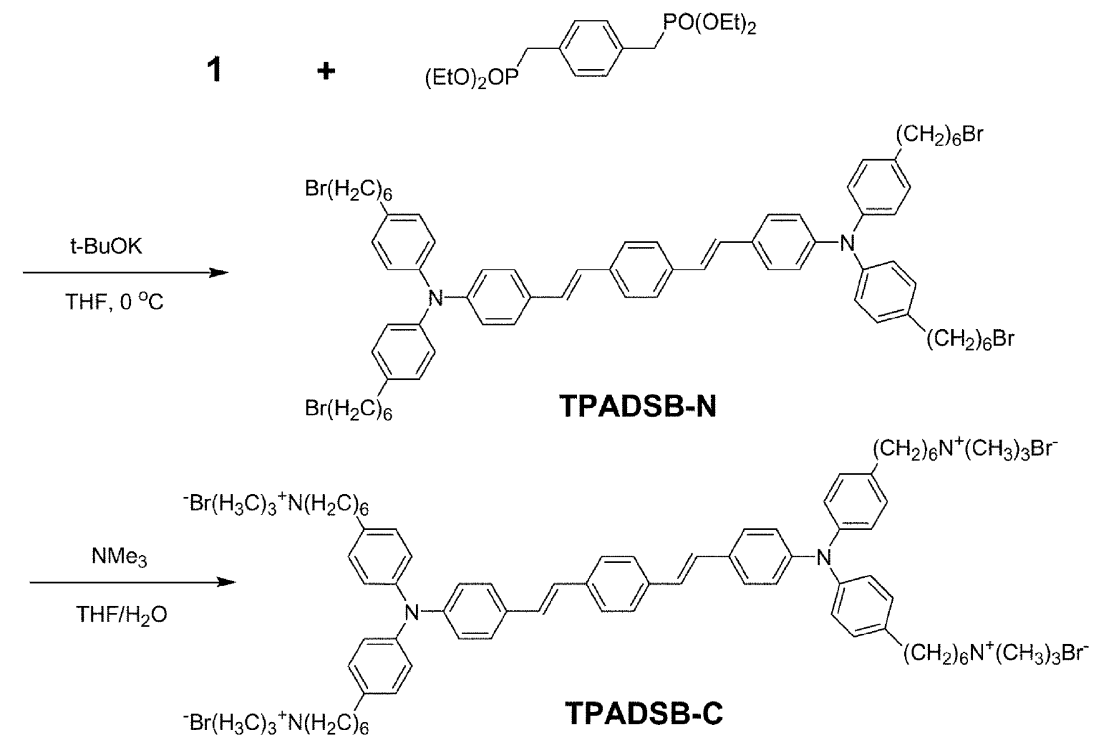

Schone I. Synthetic routes to TPADSB-Y and TPADSB-C.

\section{RESULTS AND DISCUSSION}

PSAU was obtained by lree radical polymerization of sodium acrylamidoundecanoate in water using $\mathrm{K}_{2} \mathrm{~S}_{2} \mathrm{O}_{8}$ as a radical initiator. ${ }^{9}$ The linal polyner was purified by dialysis using $12 \mathrm{kDa}$ nolecular weight cut ofl bags against alkaline water $(\mathrm{pl} 1-10)$. For the synthesis of compound 1 (Scheme 1), triphenylamine was brominated with $\mathrm{N}$-bromosuceinimide in dichloronethane and the successive lithiation/alkylation with t-BuLi and excess 1,6-dibromohexane yielded bis[4-(6 -bromohexyl)phenyl]phenylamine in $63 \%$ yield. To prevent intermolecular coupling reactions, a large excess ( 10 eq.) of 1,6-dibromohexane was added. Aldehyde functionality was easily introduced by Vilsmeier formylation to give the structure 1 in $78 \%$ yield. I Iorner-Emmons Wittig coupling between 1,4-bis(diethylphosphonatemethyl)bencene and 2 \%. of compound $\mathbf{l}$ using potassium ter1-butoxide in THIF at $0^{\circ} \mathrm{C}$ gave TPADSB-N. The reaction temperature was kept around $0^{\circ} \mathrm{C}$ in order 10 renove the possibility of halide climination during the reaction. Formation of the final water-soluble TPADSBB-C was casily achicved via quatemization with a large excess of trimethylamine in the mixed solvent of $\mathrm{THF}$ and water. After addition of trimethylanine, the insoluble solid forns gradually as the reaction proceeds, which means the ionic units are formed 
via quaternization. To ensure that complete quaternization is achieved, it is recommended to re-dissolve the precipilated compounds by adding water and to add excess trimethylanine for a further reaction. Removal of unreacted trimethylamine does not impose any problem because of its low boiling point.S

The surfactant units in the polymer chain can assemble in a way to form unimolecular micelles in aqueous solution. This process is expected to be independent on the polymer concentration [PSAU]. On the other hand, the polymer chains can also undergo self-organization to form inter-chain aggregates at higher concentrations. In order to examine hydrophobic domain formation, we have perfomed fluoresence probe studies using NPN as a probe molecule. Though NPN is weakly fluoreseent in aqueous solution, its fluorescenec spectrum in the presence of PSAU shows 8 times intensity increase accompanied by a $52 \mathrm{~nm}$ blue-shift (Fig. 2). This suggests that the probe molecules are solubilized in nonpolar environments within the polymer aggregates. $^{|i-| l}$

The change of relative fluorescence intensity $(/ / \%$, where / and /o are the fluorescenee intensities of NPN in the presence and absence of polymer. respectively) with increasing polymer concentration is shown in Fig. 3. Large enhaneement of $/ / \%$ at higher polymer concentrations indicates the formation of inter-chain aggregates. The corresponding shift of the enission maximum of $\mathrm{NPN}\left(\Delta \hat{\lambda}_{-}\right.$ $\lambda_{\text {ill water }}-\lambda_{\text {in 15AL solutisur }}$ ) is also plotted as a function of

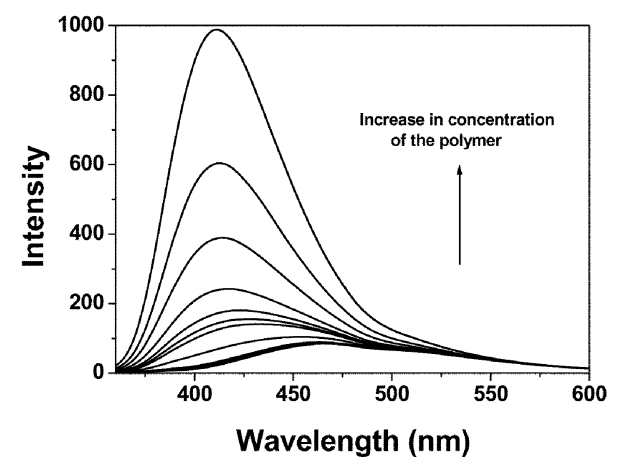

Fig. 2. Fluerescence spectra of NPN with increasing $\mid$ PSAU|.

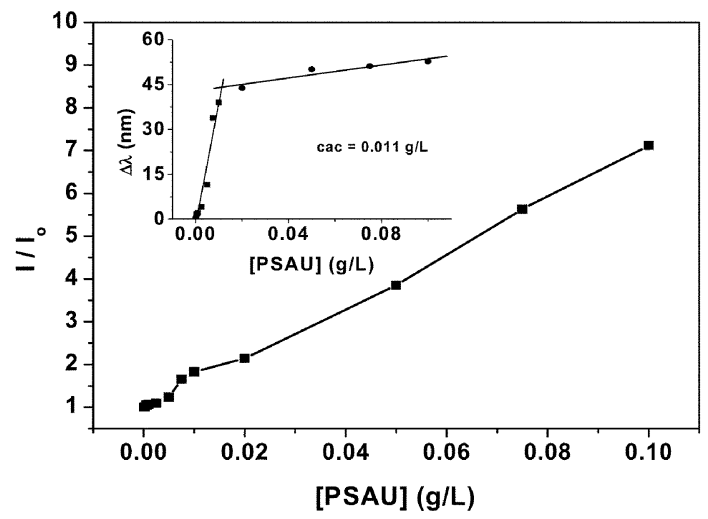

Fig. 3. Plot of relative PI. intensity (I/o) of NPN as a function of [PSAU]. Inset) plot of the shifl of cmission maximum of $\mathrm{NP}^{P} \mathrm{~N}$ as a linction of [PSAL;].

polymer concentration (Inset /ig. 3). Although spectral shift shows saturation after complete solubilization of the probe within the hydrophobic domains of polymer aggregates, the enission intensity keeps increasing. The plot shows that the onset of interchain aggregation occurs at polymer concentration of $\sim 0.01 \mathrm{gL}^{-1}$. In analogy with the critical micelle concentration (cmc) of monomeric surlactants, the concentration cortesponding to the inflection point can be referred as a critical aggregation concentration (cac). Thus, cac of PSAU oblained from the plot is about $0.01 \mathrm{gL}^{-1}$. The absenec of any concentration-independent region at low $\lceil\mathrm{PS} \boldsymbol{\Lambda} \mathrm{U}\rceil$ (inset Fig. 3) suggests that single polymer chain has also hydrophobic domains that can bind the probes in dilute aqueous solutions.

Fig. 4 shows absorption and PL spectra of TPADSB$\mathbf{N}$ in toluene and TPADSB-C in water. Both TPADSB$\mathbf{N}$ and TPADSB-C have same electronic conjugation. The charged ionic units only adjust the solubility in diflerent solvents due to break-up of $\pi$-conjuga(ion with the main chromophore backbone. The emission spectrum in water is red-shifted $\left(\lambda_{\mid, 1}=520\right.$ nim), structureless and broad relative to that in toluene $\left(\lambda_{\mathrm{I}^{\prime \prime}}=457 \mathrm{~nm}\right)$. The absorption spectra in toluene $\left(\lambda_{\text {ill }}-415 \mathrm{~nm}\right)$ and in water $\left(\lambda_{\text {ill }}-408 \mathrm{~nm}\right)$ show a negligible difference and a slight blue-shift in water is originated from conformational distortion due to poor solubility and/or hydrogen bond-

2007. list. 5 . . . 6 


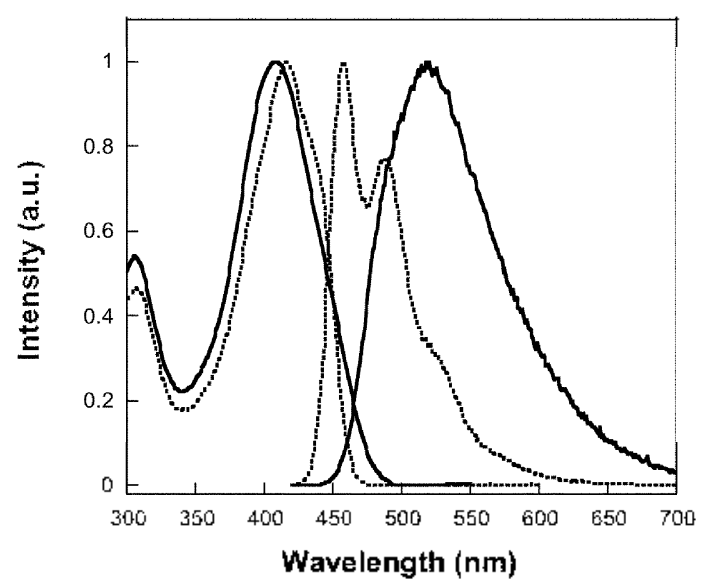

Fig. 4. UVy-vis itrsorplion ind IJuorescence spectra of TPADSB-N in toluche (doted linc) and TPADSB-C in waler (solid linc).

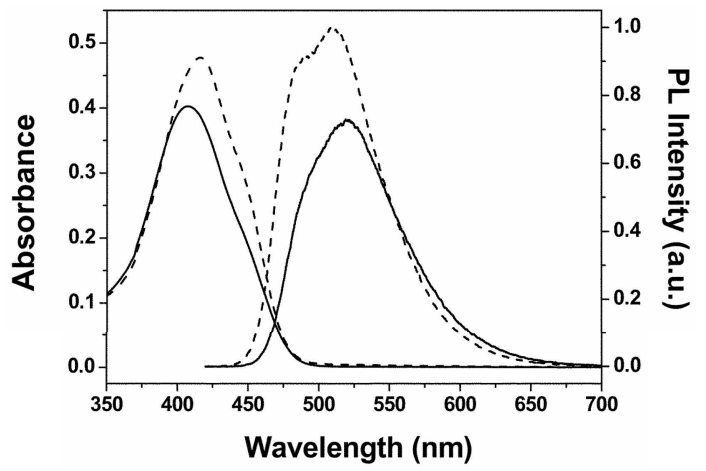

Fig. 5. Ahsorption and tluoresence spectra of TPADSB-C in water (soljd line) and in PSAU vesicle solution (doted line).

ing interaction with water.

The steady-state P'L and UV-vis spectra of TPADSBC ([TPADSB-C] $\left.-1 \times 10^{-1 /} \mathrm{M}\right)$ in the presence and absence of PSAU in water are presented in Fig. 5. The PSAU concentration $(3 \mathrm{~g} / \mathrm{L})$ was adjusted to exceed its cac $(\sim 0.01 \mathrm{~g} / \mathrm{L})$ for complete formation of inter-chain vesicles. The entission o[ TPADSB-C is blue-slifled $\left(\hat{\lambda}_{\mathrm{p} \mid}-520 \mathrm{~nm} \rightarrow 510 \mathrm{~nm}\right)$ in PSAU solution due to incorporation of the chromophores inside of the vesicles. The PL quantum efficiency ( $\left(\mathrm{D}_{\mathrm{pl}}\right.$ ) of the chromophore was measured relative to tluorescein in water $(\mathrm{pH}-10)$. The $\Phi_{\mathrm{Pr}}$ of TPADSB-C in water is $73 \%$ in the absence of PSAU and $90 \%$ in the presence of PSAU vesicle. The entancenent in the quantum elficiency is caused by the nonpo- lar microenviromment around the chromophores due to inclusion inside the PSAU vesicle. The inside of bilayers of the vesicle is hydrophobie and nonpolar relative to water, which is similar to organic solvents. TPADSB-C is water-soluble with charged ionic groups but the main conjugated backbone is still hydrophobic. The chromphores are expected to exist in the bilayers through hydrophobic interactions. Molar absorptivity of the chromophore is also increased with the PSAU vesicles (Fig. 5).

It is interesting to mention that the fluorescence spectrum with PSAU shows a blue-shilted emission with enhaneed $\Phi_{\mathrm{pr}}(90 \%)$ but it is different from the spectra in toluene and in water. However same UV-vis and PL spectra of TPADSB-C in a sodium dodecylsulfate (SDS) micelle were reported with regard to those of TPADSB-N in toluene." It is expected that the microenvironment inside the SIOS micelle is very sinilar to nonpolar organic solvents such as toluene, which is not the same case with the PSAU vesicle. There are two different micro domains inside the vesicle, the aqueous core and the hydrophobic bilayer. TPADSB-C can exist in both of the core and the bilayer. The measured absorption and PL specira of TPADSB-C in PSAU vesicles are intermediate between those in toluene and water. The ehromophores in two diflerent micro domains probably contribute together to the resulting spectrat The polymeric vesiele is a very interesting microcontainer which modulates the microenvironment (such as polarity) around the molecular fluorophores in bulk aqueous solution. The encapsulated fluorophores inside the vesicle have a great potential as efficient molecular labels with biocompatibility in biological imaging using confocal microscopy and two-photon induced fluorescence microscopy.

In summary, an inter-chain vesicle formation of poly(sodium acrylamidoundecanoate) (PSAU) was studied using NPN fluoreseenec measurement with changing PSAU concentration in water. PSAU shows a critical aggregation concentration at $-0.01 \mathrm{~g} / \mathrm{L}$. Above cac, UV-vis and fluorescence spectroscopy of the water-soluble fluorophore (TPADSB-C) was investigated to study the nicroenvironment modulation through dye incorporation in the polymeric 
vesicle. The emission of TPADSB-C in the presence of PSAL vesicles was blue-shifted and the PL quantum efficiency was increased to $90 \%$ due to the microenvironment (e.g. polarity) change in aqueous solution. This study shows that the polymeric vesicle containing molecular fluorophores has a great potential as efficient, stable and biocompatible labeling tags in biological cell inaging.

Acknowledgement. This work was supported for two years by Pusan National Lniversity Research Grant.

\section{REFERENCES}

1. Kishimura, A.; Koide, A.; Osada, K.; Yamasaki, Y; Kataoka, K. Angew: Chem. Int. Ed. 2007, 46, 6085.

2. Holowka, E.; Sun, V. Z.; Kamei, D. T; Deming, T. J, Nat. Mater: 2007, 6, 52.

3. Ma, Y.; Dong, W.-F.; Hempenius, M. A.; Mohwald, H.;
Vancso, G T. Nat. Mater: 2006, 5, 724.

4. Ranquin, A.; VersLes, W; Meier, W. ; Steyaert, J.; Gelder, P. V. Nano Letr. 2005, 5, 2220.

5. Bellomo, E. G; Wyrsta, M. D.; Pakstis, L.; Pochan, D. J.; Deming, T. T. Nat. Water: 2004, 3, 244.

6. Sumida, Y; Masuyama, A; Takasu, M; Kida, T.; Nakatsuji, Y; Ikeda, I. Langmir 2001, 17, 609.

7. Lasic, D. D; Needlam, D. Chem. Rev 1995, 9.5, 2601.

8. Kusumi, A.; Singh, M.; Tirrell, D. A.; Oelme, G; Singh, A.; Sanuel, N.K.P.; Hyde, J. S.; Ressen, S. L. J. Am. Chem. Soc. 1983, 105, 2975.

9. Nayak, R. R; Roy, S; Dey, J. Colloid Polym. Sci. 2006, 285, 219.

10. Gan, L. M:- Chew, C. H. In Shafactant Science Series; Friberg, S. E.; Lindnan, B., Ed; Marcel Dekker, Inc., New York, 1992, 44, 327.

11. Tohuu, S.; Keita, T.; Masataka, H. Anal. Chim Acta. 2002, 454, 203.

12. Woo, H. Y.; Korystov, D.; Mikhailovsky, A; Nguyen, T.Q.; Bazan, G C. J. Am. Chem. Soc 2005, 127, 13794. 